\title{
Possible implications from results of animal studies in human risk estimations for benzene: nonlinear dose-response relationship due to saturation of metabolism
}

\author{
Sandro Grilli ${ }^{1}$, Werner K. Lutz ${ }^{2}$, and Silvio Parodi ${ }^{3 *}$ \\ ${ }^{1}$ Centro Interuniversitario per la Ricerca sul Cancro and Istituto di Cancerologia dell'Università di Bologna, \\ viale Filopanti 22, I-40126 Bologna, Italy \\ 2 Institute of Toxicology, ETH and University of Zürich, CH-8603 Schwerzenbach, Switzerland \\ ${ }^{3}$ Centro Interuniversitario per la Ricerca sul Cancro and Istituto Nazionale per la Ricerca sul Cancro, viale Benedetto XV, 10 , \\ I-16132 Genova, Italy
}

Summary. To date, all risk assessment studies on benzene have been based almost exclusively on epidemiological data. We have attempted a more integrated and quantitative evaluation of carcinogenic risk for humans, trying to utilize, in addition to the epidemiological data, all data available, specifically data on metabolism, genotoxicity, and carcinogenicity in small rodents. An integrated evaluation of the globality of the available data seems to suggest a progressive saturation of metabolic capacity both for man and rodents between 10 and $100 \mathrm{ppm}$. The most susceptible target cells seem to be different in humans (predominant induction of myelogenous leukemia) and small rodents (induction of a wide variety of tumors). Nevertheless, both epidemiological and experimental carcinogenicity data tend to indicate a flattening of the response for the highest dosages, again suggesting a general saturation of mechanisms of metabolic activation, extended to different target tissues. From a quantitative point of view, the data suggest a carcinogenic potency at 10 ppm two to three times higher than that computable by a linear extrapolation from data in the $100 \mathrm{ppm}$ range. These observations are in accord with the recent proposal of the European Economic Community of reducing benzene time-weighted average occupational levels from 10 to $5 \mathrm{ppm}$.

Key words: Benzene - Risk estimation - Carcinogenicity - Genotoxicity - Metabolism saturation - Dose-response relationship

\section{Introduction}

Benzene is probably the chemical with the largest production and utilization in the world (IARC 1982a). As a consequence, both occupational exposure and en-

* Contributions to this work by Dr. Annamaria Colacci ${ }^{1}$, Mario Mazzullo ${ }^{1}$, and Maurizio Taningher ${ }^{3}$ are gratefully acknowledged Offprint requests to: S. Grilli vironmental contamination occur to a rather significant extent. Benzene has been recognized for many years as a carcinogen in humans with the induction of acute myelogenous leukemia (IARC 1982a). The most common regulatory standard for occupational exposure in industrialized countries is a limit of 10 ppm (time-weighted average TWA) (IARC 1982a). For the corresponding risk assessment often only epidemiological data have been considered (IARC 1982 a). Correlations with carcinogenicity data in rodents have less frequently been established (Lee et al. 1983).

In this paper, we have tried to enrich current information by compiling the data related to genotoxicity versus nongenotoxicity in the mechanism of action of benzene, by comparing metabolism in humans and rodents, and by pharmacokinetic considerations of a possible saturation of benzene metabolism and genotoxicity at higher exposure levels.

\section{Epidemiological data}

In the annex to the IARC Monographs on the Evaluation of the Carcinogenic Risk of Chemicals to Humans, vol 29 (IARC 1982b), a working group attempted a quantitative risk estimation for benzene, based entirely on human epidemiological data. Minimum estimates of 14-170 excess leukemia deaths per 1000 workers exposed over a working lifetime were calculated for an exposure level of $100 \mathrm{ppm}$. Their computations were based on three epidemiological studies (Vigliani 1976; Ott et al. 1978; Rinsky et al. 1981) for which ranges of excess cases and exposure levels are shown in Fig. 1. Using the words of the authors (IARC 1982 b): "The working group found that quantitative estimation was more feasible than seemed initially to be the case. The group was impressed that rather large amounts of quantitative information could be extracted from the published epidemiological data and that reasonable risk estimations could then be based on that information."

The IARC estimate is in rather good agreement with the estimate of Goldstein (1985). The lifetime risk per parts per million computed by this author was apparently about 10 times higher than the lifetime risk computed by the IARC Group. The difference is only apparent and due to the fact that in the Goldstein computations a continuous life exposure was considered, whereas in the computa- 


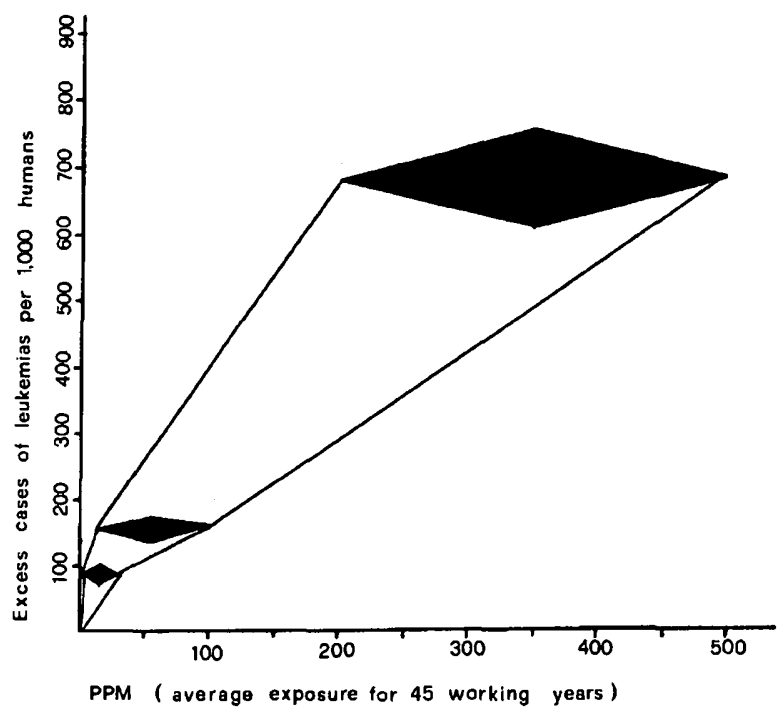

Fig. 1. Leukemia incidence in workers exposed to benzene (computations made by IARC Working Group, IARC 1982 a). Ranges of benzene concentration include variations in exposure levels and uncertainty in analytical determinations performed by "old" methods which had a precision of $\pm 50 \%$ (Rinsky et al. 1981)

tions of the IARC Group the exposure was referred to $40 \mathrm{~h} /$ week for 45 years. When the computations of Goldstein are corrected according to the standard of exposure utilized by the IARC Group, the excess cases of leukemia deaths expected for $100 \mathrm{ppm}$ become $332 / 1000$ workers, in good agreement with the value deduced from Fig. 1. In the Goldstein computations, two out of three epidemiological studies were the same as those utilized by the IARC Group.

\section{Carcinogenicity in animals}

To our knowledge, the first suggestion that benzene could be carcinogenic in small rodents came from work published in 1979 by Maltoni and Scarnato. The induction of Zymbal gland carcinoma in female rats was statistically significant $(P=0.0031)$ at $250 \mathrm{mg} / \mathrm{kg}$ (administered by gavage once daily, 4-5 days each week, for 52 weeks).

A suggestion that benzene could be carcinogenic in small rodents upon inhalation came from a work published in 1980 by Snyder et al. Benzene was given to $\mathrm{C} 57 \mathrm{BL} / 6 \mathrm{~J}$ mice at a concentration of $300 \mathrm{ppm}, 6 \mathrm{~h} /$ day, 5 days/week, for life. Eight hematopoietic tumors were found in 40 treated animals, whereas only 2 were found in 40 controls. The difference was suggestive but only borderline from a statistical point of view $(\mathrm{P}=0.044$, one-tailed, according to the Fisher exact test).

After the publication in 1982 of the work of the IARC group on quantitative cancer risk estimation based only on epidemiological data (IARC 1982 b), the carcinogenicity of benzene in small rodents was better defined und confirmed (NTP 1984; Cronkite et al. 1985; Maltoni et al. 1985). An overall picture of the results that we have considered relevant is presented in Table 1. Differences in strain susceptibility and in route of administration can be observed: SpragueDawley rats are less susceptible than Fischer 344 rats to benzene administered by gavage. A quantitative comparison of the carcinogenicity results from oral with inhalation exposure could not be made because we could not find enough data on serum levels of benzene at different concentrations and times after beginning of treatment.

If we confine ourselves to the high dose inhalation experiments of Maltoni et al. (1985), we can compute a tumor incidence over controls (animals with at least one tumor) of 0.27 for an average continuous concentration (on the basis of $8 \mathrm{~h} /$ day, 5 days a week) of 243 ppm for 2 years [a different value (TWA $=284 \mathrm{ppm}$ ) is reported in the legend of Table 1 , but this value refers to a daily exposure of $4 \mathrm{~h}$ for 7 weeks plus $7 \mathrm{~h}$ for 97 weeks], equivalent approximately to an incidence over controls of $111 / 1000$ animals for $100 \mathrm{ppm}$ for rat lifespan. If we consider the inhalation experiment with mice of Snyder et al. (1980), we can compute a tumor incidence over controls of 0.15 for an average continuous concentration of $225 \mathrm{ppm}$ for 2 years, equivalent approximately to an incidence over controls of 67/1000 animals for 100 ppm for mouse lifespan. Considering carcinogenic potencies can span a range of more than $10^{7}$ times (Parodi et al. 1982; Peto et al. 1984), a difference by a factor

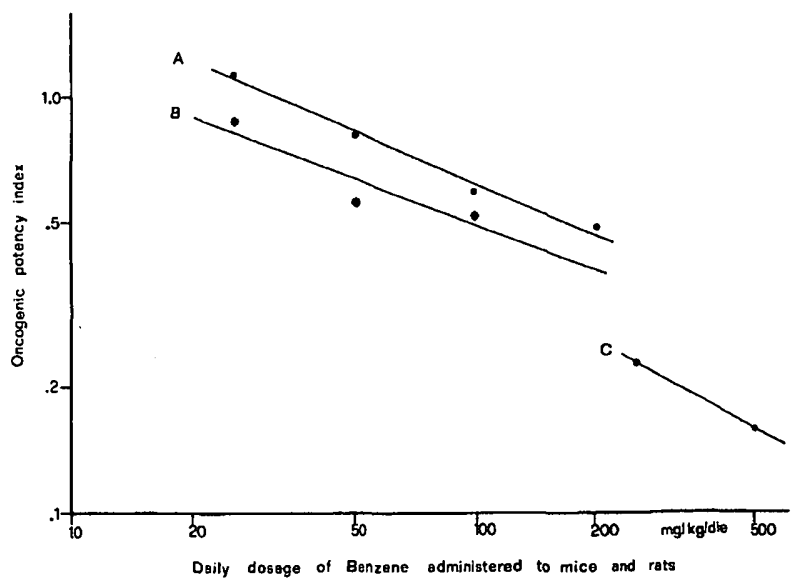

Fig. 2. Oncogenic potency index (OPI) as a function of dosage of benzene in mice and rats. OPI $=-\ln (1-I) / D t$, where $I$ is the excess incidence over controls (proportion of animals with at least one malignant tumor for all tumors), $t$ is the length of observation (time unit= 2 years) and $D$ is the dosage in millimoles per kilogram per day equivalent to the total dose divided by a 2-year exposure (Parodi et al. 1982). Only dosages which produced statistically significant effects $(P<0.05)$ were considered. These data are not directly comparable with those of Table 1 where malignant tumor incidences of different target organs are reported. $A=F 344$ rats, gavage (NTP 1984); $\mathrm{B}=\mathrm{B} 6 \mathrm{C} 3 \mathrm{~F} 1$ mice, gavage (NTP 1984); $\mathrm{C}=\mathrm{S}-\mathrm{D}$ rats, gavage (Maltoni et al. 1985) 
Table 1. Malignant tumors observed in long-term assays of benzene carcinogenicity in rodents

\begin{tabular}{|c|c|c|c|c|c|c|c|c|c|c|}
\hline \multirow[t]{3}{*}{ Species } & \multicolumn{10}{|c|}{ Route of administration } \\
\hline & \multicolumn{5}{|l|}{ Inhalation } & \multicolumn{5}{|l|}{ Gavage } \\
\hline & $\begin{array}{l}\text { Main target } \\
\text { organs }^{\mathbf{a}}\end{array}$ & $\begin{array}{l}\text { Tumor } \\
\text { incidence } \\
\text { over } \\
\text { controls }\end{array}$ & $\begin{array}{l}\text { TWA } \\
\text { chronic } \\
\text { dose } \\
\text { (ppm) }\end{array}$ & $\begin{array}{l}\mathrm{Re}- \\
\text { sponse }\end{array}$ & Strain & $\begin{array}{l}\text { Main target } \\
\text { organs }^{\mathrm{a}}\end{array}$ & $\begin{array}{l}\text { Tumor } \\
\text { incidence } \\
\text { over } \\
\text { controls }\end{array}$ & $\begin{array}{l}\text { Chronic } \\
\text { dose } \\
\text { (mg/kg } \\
\text { perday) }\end{array}$ & $\begin{array}{l}\text { Re- } \\
\text { sponse }\end{array}$ & Strain \\
\hline \multirow[t]{9}{*}{ Rat } & Zymbal glands & 0.093 & 284 & $(++)$ & $S-D^{b}$ & Zymbal glands & 0.22 & 100 & $(++)$ & F344 ${ }^{\circ}$ \\
\hline & Oral cavity & $0.079^{\mathrm{d}}$ & 284 & $(++)$ & $S-D^{b}$ & Zymbal glands & 0.42 & 500 & $(++)$ & $S-D^{b}$ \\
\hline & Liver (hepatomas) & $0.108^{\mathrm{d}}$ & 284 & $(++)$ & S-D $D^{b}$ & Oral cavity & 0.19 & 50 & $(++)$ & F344 \\
\hline & Breast & $0.084^{d}$ & 284 & $(+)$ & $S-D^{b}$ & Oral cavity & 0.52 & 500 & $(++)$ & $S-D^{b}$ \\
\hline & Nasal cavity & 0.021 & 284 & $(+)$ & $S-D^{b}$ & $\begin{array}{l}\text { Liver } \\
\quad \text { (angiosarcoma) }\end{array}$ & 0.063 & 500 & $(+)$ & $S-D^{b}$ \\
\hline & & & & & & Skin & $0.23^{\mathrm{e}}$ & 500 & $(+)$ & $S-D^{b}$ \\
\hline & & & & & & Skin & $0.16^{\mathrm{e}}$ & 200 & $(+)$ & F344 ${ }^{\mathrm{c}}$ \\
\hline & & & & & & Nasal cavity & 0.05 & 500 & $(+)$ & $S-D^{b}$ \\
\hline & & & & & & $\begin{array}{l}\text { Forestomach } \\
\quad \text { (in situ ca.) }\end{array}$ & $0.15^{\mathrm{d}}$ & 500 & $(+)$ & $S-D^{b}$ \\
\hline \multirow[t]{4}{*}{ Mouse } & $\begin{array}{l}\text { Hematopoietic } \\
\text { system }^{1}\end{array}$ & $0.15^{\circ}$ & 300 & $( \pm)$ & $\mathrm{C} 57 \mathrm{BL} / 6^{8}$ & Zymbal glands & 0.24 & 100 & $(++)$ & $\mathrm{B} 6 \mathrm{C} 3 \mathrm{~F} 1^{\mathrm{c}}$ \\
\hline & $\begin{array}{l}\text { Hematopoietic } \\
\text { system }^{\mathbf{f}}\end{array}$ & $0.145^{\mathrm{d}}$ & 300 & $(+)$ & $\mathrm{C} 57 \mathrm{BL} / 6^{\mathrm{h}}$ & $\begin{array}{l}\text { Liver (adenomas + } \\
\text { carcinomas) }\end{array}$ & $0.14^{d}$ & 100 & $(++)$ & $\mathrm{B} 6 \mathrm{C} 3 \mathrm{~F} 1^{\mathrm{c}}$ \\
\hline & Ovary & $0.09^{d}$ & 300 & $(+)$ & $\mathrm{C} 57 \mathrm{BL} / 6^{\mathrm{h}}$ & $\begin{array}{l}\text { Hematopoietic } \\
\text { system }^{f}\end{array}$ & 0.16 & 25 & $(+)$ & $\mathrm{B}^{6 \mathrm{C} 3 \mathrm{~F} 1^{\mathrm{c}}}$ \\
\hline & Zymbal glands & $0.17^{\mathrm{d}}$ & 300 & $(+)$ & $\mathrm{C} 57 \mathrm{BL} / 6^{\mathrm{h}}$ & $\begin{array}{l}\text { Breast } \\
\text { Lung (adenomas) }\end{array}$ & $\begin{array}{l}0.275^{\mathrm{d}} \\
0.22\end{array}$ & $\begin{array}{l}500 \\
500\end{array}$ & $\begin{array}{l}(+) \\
(+)\end{array}$ & $\begin{array}{l}\text { Swiss }{ }^{b} \\
\text { Swiss }^{b}\end{array}$ \\
\hline
\end{tabular}

${ }^{a}$ Tumor incidence in treated groups was higher than that of controls from a statistical point of view $(P<0.05)$. Only the most effective dosage was reported

b Maltoni et al. (1985). In inhalation studies, S-D rats were exposed to benzene pre- and postnatally [4-7 h/day, 5 days/week for 104 weeks (TWA $=284 \mathrm{ppm}$ ) or 15 weeks $($ TWA $=200 \mathrm{ppm})]$. Experiments with Wistar rats and Swiss mice are ongoing (100-week study). Tumor incidences from this work have been calculated by referring the number of tumor-bearing animals to the correct number (i.e., the number of survivors at the time that the first tumor appeared, regardless of the organ considered)

' NTP study (1984). Malignant tumors of lung, breast, and preputial glands were also induced

'Only in females

- Only in males

' Malignant lymphomas

${ }^{8}$ Snyder et al. (1980). Mice were exposed for $6 \mathrm{~h} /$ day, 5 day/week for life. A single dose was tested

${ }^{b}$ Cronkite et al. (1985). Subchronic exposure (16 weeks) and 99-week observation. A single dose was tested

TWA $=$ time-weighted average. $F 344=$ Fischer 344 rats. $S-D=$ Sprague-Dawley rats. $(++)=$ dose-related tumor induction. $(+)=$ doseunrelated tumor induction. $( \pm)=$ borderline evidence of tumor induction $(0.1>P>0.05)$

of 2 to 5 between small rodents and humans is remarkably small. Obviously, in making this statement we imply that the ratio of tumor latency to lifespan is essentially the same for both humans and small rodents. Most experimental evidence seems to favor this broad assumption (behind this apparently simple hypothesis very complex problems are hidden when considering carcinogenesis as a multistep process. Mutation-like events seem to have a similar frequency in human and rodent cells, but perhaps the number of steps is different in the two species, in order to adjust latency to the respective lifespan). The dosage extrapolations at low levels of risk, performed by the USA Environmental Protection Agency (Lee et al. 1983; Goldstein 1985), showed a similar picture of concordance between human and animal data.
From the point of view of overall tumor frequency small rodents and humans showed very similar sensitivity. Considering target organ, only few leukemias (usually not of the myeloid type) were induced in rodents. Zymbal glands and oral cavity were the primary targets in rodents, but neoplastic effects were also observed in liver and breast, and occasionally in skin, nasal cavity, lung, forestomach, adrenals, ovary, Harderian and preputial glands (Table 1). We are aware that the application of animal data (as proposed here) to humans would be safer if not only a quantitative but also a qualitative similarity of tumor incidences had been shown in the two systems.

Some indication of a possible dose-response relationship is offered by the experiments when benzene was given by gavage. In Fig. 2 the oncogenic potency 
Table 2. Short-term assays of potential carcinogenicity of benzene: evaluation of most genotoxicity data from literature. Figures indicate the number of short-term assays which were either positive $(+)$ or negative $(-)$. Unless otherwise indicated, data are taken from IARC (1982a, c), ECETOC (1984) and Dean (1985) reviews. Data lacking in experimental details, equivocal for the authors or for IARC working group, or successively changed by the same authors after having modified experimental design, have not been considered

\begin{tabular}{|c|c|c|c|c|c|c|c|c|c|c|c|c|}
\hline \multirow{3}{*}{$\frac{\text { System }}{\text { Prokaryotes }}$} & \multicolumn{3}{|c|}{ DNA damage } & \multicolumn{3}{|c|}{ Mutation } & \multicolumn{3}{|c|}{$\begin{array}{l}\text { Chromosome } \\
\text { anomalies }\end{array}$} & \multicolumn{3}{|c|}{ Other } \\
\hline & \multirow{2}{*}{$\frac{(+)}{0}$} & & \multirow{2}{*}{$\frac{(-)}{2}$} & \multicolumn{2}{|l|}{$(+)$} & \multirow{2}{*}{$\begin{array}{c}(-) \\
1^{a} \\
7 \\
5^{b}\end{array}$} & \multirow[t]{2}{*}{$(+)$} & \multicolumn{2}{|c|}{$(-)$} & \multicolumn{2}{|c|}{$(+)$} & \multirow[t]{2}{*}{$(-)$} \\
\hline & & pol A & & $\begin{array}{l}0 \\
0 \\
0\end{array}$ & $\begin{array}{c}\text { ST } \\
\text { ST, BS } \\
\text { ST }\end{array}$ & & & & & & & \\
\hline Fungi/green plants & & & & $\begin{array}{l}0 \\
5^{b} \\
2\end{array}$ & $\begin{array}{c}\text { SC } \\
\text { GM, GC, CO } \\
\text { TRD }\end{array}$ & $\begin{array}{c}1 \\
16^{b} \\
0\end{array}$ & $3^{b}$ & A & $1^{b}$ & & & \\
\hline Insects & & & & $\begin{array}{l}0 \\
1^{b}\end{array}$ & $\begin{array}{l}\text { RM } \\
\text { RM }\end{array}$ & $\begin{array}{l}1 \\
2^{b}\end{array}$ & & & & & & \\
\hline Amphibians & & & & & & & $1^{\mathrm{a}}$ & $\mathrm{CA}$ & 0 & & & \\
\hline $\begin{array}{l}\text { Mammalian cells } \\
\text { (in vitro) }\end{array}$ & $\begin{array}{l}1^{c} \\
1^{d} \\
1^{b} \\
2^{b}\end{array}$ & $\begin{array}{c}\text { MtMBI } \\
\text { MMBI } \\
\text { AE } \\
\text { UDS }\end{array}$ & $\begin{array}{l}0 \\
0 \\
2^{b} \\
4^{b}\end{array}$ & $\begin{array}{l}0 \\
6^{b}\end{array}$ & $\begin{array}{c}\text { L5178Y } \\
\text { L5178Y,V79, } \\
\text { CHO, HL }\end{array}$ & $\begin{array}{l}1 \\
9^{b}\end{array}$ & $\begin{array}{l}1 \\
1^{\mathrm{a}} \\
7 \\
3^{\mathrm{b}} \\
2^{\mathrm{b}} \\
2 \\
0 \\
0\end{array}$ & $\begin{array}{c}\text { A } \\
\text { CA } \\
\text { CA } \\
\text { CA } \\
\text { A/P } \\
\text { SCE } \\
\text { SCE } \\
\text { MN }\end{array}$ & $\begin{array}{l}0 \\
0 \\
1 \\
4^{b} \\
3^{b} \\
1 \\
6^{b} \\
1^{b}\end{array}$ & $\begin{array}{l}0 \\
3^{b}\end{array}$ & $\begin{array}{l}\text { MC } \\
\text { TR }\end{array}$ & $\begin{array}{l}3^{b} \\
5^{b}\end{array}$ \\
\hline Mammals (in vivo) & $\begin{array}{l}1^{\mathrm{e}} \\
2^{\mathrm{B}}\end{array}$ & & $\begin{array}{l}1^{f} \\
0\end{array}$ & 0 & & $1^{b}$ & $\begin{array}{c}13 \\
1^{\mathrm{i}} \\
2 \\
11 \\
1^{\mathrm{j}}\end{array}$ & $\begin{array}{l}\text { CA } \\
\mathrm{CA} \\
\mathrm{SCE} \\
\mathrm{MN} \\
\mathrm{MN}\end{array}$ & $\begin{array}{l}1 \\
0 \\
0 \\
0 \\
0\end{array}$ & 0 & $\mathrm{DL}$ & 1 \\
\hline Humans (in vivo) & & & & & & & $\begin{array}{c}19 \\
4^{\mathrm{a}} \\
0\end{array}$ & $\begin{array}{l}\mathrm{CA} \\
\mathrm{CA} \\
\mathrm{SCE}\end{array}$ & $\begin{array}{l}2 \\
0 \\
2\end{array}$ & & & \\
\hline Class positivity: & & $17=47.1^{\circ}$ & & & $14 / 58=24.1 \%$ & & $71 /$ & $3=76.3$ & & & $2=25$. & \\
\hline Overall activity (pos & /total & tests): & & & & $96 / 1$ & $3 \%$ & & & & & \\
\hline
\end{tabular}

From Lee et al. (1983)

brom Table 1 of ICPS collaborative study of Ashby et al. (1985)

c From Kalf et al. (1985)

d From Arfellini et al. (1985)

- From Parodi et al. (1983) alkaline elution

' From Parodi et al. (1983) viscosimetric unwinding

${ }^{8}$ From Lutz and Schlatter (1977b) and Arfellini et al. (1985) DNA adducts

${ }^{\text {h }}$ Point mutation in rat chromosomes

i From Gad-el-Karim et al. (1984)

J From Choy et al. (1985)

$\mathrm{CHO}=$ Chinese hamster ovary. $\mathrm{ST}=$ Salmonella typhimuritom/microsome. $\mathrm{BS}=$ Bacillus subtilis. $\mathrm{SC}=$ Saccharomyces cerevisiae. $\mathrm{GM}=$ gene mutation. $\mathrm{GC}=$ gene conversion. $\mathrm{CO}=$ crossing-over. $\mathrm{A}=$ aneuploidy. $\mathrm{RM}=$ recombination and mutation. $\mathrm{CA}=$ chromosome aberration. $\mathrm{MtMBI}=$ mitochondria-mediated binding to mitochondrial DNA. $\mathrm{MMBI}=$ microsome-mediated binding to calf thymus DNA. AE =alkaline elution. $\mathrm{UDS}=$ unscheduled $\mathrm{DNA}$ synthesis. $\mathrm{HL}=$ human lymphocytes. $\mathrm{P}=$ polyploidy $\mathrm{SCE}=$ sister chromatid exchange. $\mathrm{MN}=$ micronucleus test. $\mathrm{MC}=$ metabolic cooperation. $\mathrm{TR}=$ cell transformation. $\mathrm{DL}=$ dominant lethal test (rat). pol $\mathrm{A}=\mathrm{DNA}$ polymerase-deficient and proficient Escherichia coli. TRD = Tradescantia assay

index (OPI) computed according to Parodi et al. (1982) for increasing benzene dosages is reported, and suggests a higher relative sensitivity to the carcinogenic effect of benzene at lower dosage. Carcinogenicity data in rodents for vinyl chloride given by inhalation also showed typical flattening of the response at the highest dosages (Maltoni 1975). However, in the case of benzene, dose-response experiments with inhalation exposure are not available. A quantitative correlation between human and animal data was reported by Rall (1977) for chlornaphazine, benzidine, diethylstilbestrol, and tobacco smoke. 


\section{Short-term tests}

The qualitative results obtained with short-term assays are illustrated in Table 2 . As is typical of a compound examined in many different short-term tests and in many laboratories, there are a mixture of positive and negative results. In order to express a global opinion on the data, we have followed the approach suggested by Ashby et al. (1985). These authors have examined the results obtained with short-term tests, performed in 66 different laboratories, on 10 different chemicals. Clearly genotoxic and carcinogenic compounds like acrylonitrile and toluidine were positive in $40 \%-60 \%$ of the tests. Presumed noncarcinogens and/or nongenotoxic compounds like benzoin and caprolactam were positive in about $20 \%$ of the tests. The authors suggested that potent carcinogens with a genotoxic mechanism would be positive in $\sim 80 \%$ of the tests. Noncarcinogens could be positive in $\sim 20 \%$ of the cases. Weak carcinogens should produce an intermediate number of positive responses.

We examined all the data that could be collected on benzene without any selection or exclusion of data. Benzene appeared positive in $53 \%$ of the cases
(Table 2). In the perspective of the above considerations, the results are definitely more typical of a genotoxic carcinogen than of a noncarcinogen or nongenotoxic agent. However, looking at the results in more detail, the percent of positivity of DNA damage data was $47 \%$, whereas for point mutations and chromosomal anomalies the values were $24 \%$ and $76 \%$, respectively (Table 2). It seems reasonable that there might be something peculiar in the DNA damage induced by benzene, in the sense that the damage seemed clearly more clastogenic in vivo and in vitro than mutagenic. We have examined the publications available on chromosomal damage induced by benzene in rodents in terms of dose-response relationship after treatment in vivo (Erexson et al. 1984; Gad-el-Karim et al. 1984; Styles and Richardson 1984; Choy et al. 1985). The results obtained are shown in Table 3. The potency of the response (effect/dosage) clearly decreased from low to medium to high dosage. In the experiments where benzene was given by inhalation (Erexson et al. 1984; Styles and Richardson 1984) the net effect was only doubled when the exposure in-

Table 3. Dose-response relationship for the clastogenic activity of benzene in rodents

\begin{tabular}{|c|c|c|c|c|c|}
\hline \multirow[t]{2}{*}{ Species } & \multirow{2}{*}{$\begin{array}{l}\text { Route of } \\
\text { administra- } \\
\text { tion }\end{array}$} & \multirow{2}{*}{$\begin{array}{l}\text { Endpoint and } \\
\text { dose unit }\end{array}$} & \multicolumn{3}{|c|}{ Effect ${ }^{\mathrm{a}} /$ dosage ratio at different dosage } \\
\hline & & & Low & Medium & High \\
\hline \multirow[t]{2}{*}{$\begin{array}{l}\text { Male Swiss } \\
\text { mice }\end{array}$} & Oral $^{b}$ & $\begin{array}{l}\text { Micronuclei/1000 PCE } \\
\mathrm{mg} / \mathrm{kg}\end{array}$ & $\frac{4-2.4}{8.8^{\circ}}=\overline{0.18}$ & $\frac{6-2.4}{88}=\underline{0.04}$ & $\frac{28.7-2.4}{880}=0.03$ \\
\hline & Oral $^{b}$ & $\begin{array}{l}\text { Chromosome aberrations } \\
\text { per metaphase, } \mathrm{mg} / \mathrm{kg}\end{array}$ & $\frac{0.06-0.03}{8.8^{\mathrm{c}}}=\overline{\underline{0.0034}}$ & $\frac{0.16-0.03}{88}=\underline{\overline{0.0015}}$ & $\frac{1.1-0.03}{880}=\underline{\underline{0.0012}}$ \\
\hline $\begin{array}{l}\text { Male } \mathrm{B} 6 \mathrm{C} 3 \mathrm{~F} 1 \\
\text { mice }\end{array}$ & Oral $^{d}$ & $\begin{array}{l}\text { Micronuclei } / 1000 \mathrm{NCE} \\
\mathrm{mg} / \mathrm{kg}\end{array}$ & $\frac{2.5-1.2}{25^{\mathrm{e}}}=\underline{\underline{0.052}}$ & $\frac{5.8-1.2}{100}=\underline{\underline{0.046}}$ & $\frac{9.3-1.2}{600}=\underline{\underline{0.013}}$ \\
\hline $\begin{array}{l}\text { Male Wistar } \\
\text { rats }\end{array}$ & Inhalation ${ }^{\prime}$ & $\begin{array}{l}\% \text { cells with chromosome } \\
\text { anomalies, } \mathrm{ppm}\end{array}$ & $\frac{3.03-1.54}{10^{\mathrm{B}}}=\underline{0.15}$ & $\frac{4.45-1.54}{100}=\overline{0.030}$ & $\frac{7.81-1.54}{1000}=\underline{\underline{0.0063}}$ \\
\hline \multirow[t]{2}{*}{$\begin{array}{l}\text { Male DBA/2 } \\
\text { mice }\end{array}$} & Inhalation $^{\mathrm{h}}$ & $\begin{array}{l}\text { SCE/metaphase } \\
\text { ppm }\end{array}$ & $\frac{7.6-5.9}{10^{\mathrm{i}}}=\underline{0.17}$ & $\frac{9.5-5.9}{100}=\overline{0.036}$ & $\frac{13.8-5.9}{1000}=\overline{\underline{0.0079}}$ \\
\hline & Inhalation $^{b}$ & $\begin{array}{l}\text { Micronuclei/1000 PCE } \\
\text { ppm }\end{array}$ & $\frac{0.9-0.21}{10^{i}}=\overline{\underline{0.069}}$ & $\frac{2.03-0.21}{100}=\underline{\underline{0.018}}$ & $\frac{2.81-0.21}{1000}=$ \\
\hline
\end{tabular}

a Treated values minus control values

' Two doses were administered $24 \mathrm{~h}$ apart and animals were sacrificed $30 \mathrm{~h}$ after the first dose (Gad-el-Karim et al. 1984)

c Corresponding to $3.76 \mathrm{ppm}$ according to EPA computations (Lee et al. 1983), assuming a respiratory absorption coefficient of 0.5 and a ventilation capacity of $0.03 \mathrm{l} / \mathrm{min}$ for mouse (Gold et al. 1984)

"Subchronic treatment within NTP study (1984). Micronuclei were measured after exposure for 5 days/week for 4 months (Choy et al. 1985)

- Corresponding to $10.7 \mathrm{ppm}$ according to EPA computations (Lee et al. 1983), assuming a respiratory absorption coefficient of 0.5 and a ventilation capacity of $0.03 \mathrm{l} / \mathrm{min}$ for mouse (Gold et al. 1984)

'Exposure of $6 \mathrm{~h}$ (Styles and Richardson 1984)

${ }^{8}$ Corresponding to $7.1 \mathrm{mg} / \mathrm{kg}$ according to EPA computations (Lee et al. 1983), assuming a respiratory absorption coefficient of 0.5 and a ventilation capacity of $0.1 \mathrm{l} / \mathrm{min}$ for rat (Gold et al, 1984)

${ }^{\mathrm{h}}$ Exposure of $6 \mathrm{~h}$ (Erexson et al. 1984)

${ }^{i}$ Corresponding to $23.4 \mathrm{mg} / \mathrm{kg}$ according to EPA computations (Lee et al. 1983), assuming a respiratory absorption coefficient of 0.5 and a ventilation capacity of $0.03 \mathrm{l} / \mathrm{min}$ for mouse (Gold et al. 1984)

$\mathrm{PCE}=$ polychromatic erythrocytes. $\mathrm{NCE}=$ normochromatic erythrocytes. $\mathrm{SCE}=$ sister chromatid exchanges 
Table 4. Rank classification of potency of oncogenicity (OPI) and of DNA damaging activity (CBI) for 36 carcinogens tested in rat and mouse ${ }^{a}$ and for benzene

\begin{tabular}{|c|c|c|c|c|c|c|}
\hline & Rank & $\log _{10}$ OPI & $\log _{10} \mathrm{CBI}$ & Rank & $\log _{10}$ OPI & $\log _{10} C B I$ \\
\hline & 1 & -1.42 Anil & -0.35 Eth & 19 & $2.66 \mathrm{CP}$ & $2.06 \mathrm{NHMI}$ \\
\hline & 2 & $-0.96 \mathrm{AAB}$ & $-0.30 \mathrm{DES}$ & 20 & $2.72 \mathrm{MDAB}$ & $2.07 \mathrm{NPI}$ \\
\hline & 3 & $-0.78 \mathrm{CCl}_{4}$ & $0.212-\mathrm{NA}$ & 21 & 2.73 ENU & $2.14 \mathrm{DEN}$ \\
\hline & 4 & $-0.56 \mathrm{MMS}$ & $0.38 \mathrm{AAB}$ & 22 & $2.96 \mathrm{BP}$ & $2.16 \mathrm{AAT}$ \\
\hline & 5 & $0.00 \mathrm{CHCl}_{3}$ & $0.45 \mathrm{MCA}$ & 23 & $2.97 \mathrm{DEN}$ & $2.25 \mathrm{NPY}$ \\
\hline & 6 & $0.342-\mathrm{NA}$ & 0.57 Anil & 24 & $3.01 \mathrm{AAF}$ & 2.26 Benzid \\
\hline & 7 & 1.26 NPY & $0.83 \mathrm{DAB}$ & 25 & 3.05 HAAF & $2.26 \mathrm{EDB}$ \\
\hline & 8 & 1.40 Eth & $0.86 \mathrm{CHCl}_{3}$ & 26 & $3.06 \mathrm{EC}$ & $2.29 \mathrm{ENU}$ \\
\hline & 9 & 1.57 EDB & $1.18 \mathrm{BP}$ & 27 & 3.07 Benzid & $2.59 \mathrm{HAAF}$ \\
\hline & 10 & $1.61 \mathrm{DAB}$ & 1.35 DMBA & 28 & 3.13 DMN & $2.60 \mathrm{MMS}$ \\
\hline & 11 & $1.65 \mathrm{DMH}$ & $1.41 \mathrm{CCl}_{4}$ & 29 & $3.43 \mathrm{MNU}$ & $2.71 \mathrm{MNU}$ \\
\hline & 12 & $1.79 \mathrm{NPI}$ & $1.61 \mathrm{EC}$ & 30 & 3.52 DES & $2.75 \mathrm{AFB} 2$ \\
\hline & 13 & $2.12 \mathrm{NM}$ & $1.64 \mathrm{NM}$ & 31 & 3.60 NMust & 2.83 AFG1 \\
\hline & 14 & $2.14 \mathrm{AAT}$ & $1.79 \mathrm{CP}$ & 32 & 3.73 NHMI & $3.00 \mathrm{MNNG}$ \\
\hline & 15 & $2.23 \mathrm{MNNG}$ & 1.79 EMS & 33 & 3.73 MAMA & $3.40 \mathrm{DMH}$ \\
\hline & 16 & $2.33 \mathrm{MCA}$ & 1.82 MDAB & 34 & 3.95 AFG1 & 3.47 DMN \\
\hline & 17 & $2.35 \mathrm{AFB} 2$ & 1.92 NMust & 35 & 4.36 DMBA & 3.64 MAMA \\
\hline & 18 & 2.50 EMS & $2.03 \mathrm{AAF}$ & 36 & 4.41 AFB1 & 4.09 AFB1 \\
\hline \multicolumn{7}{|l|}{ Benzene: O } \\
\hline
\end{tabular}

a Data from Parodi et al. (1982)

b F-344 rats, gavage (NTP study 1984)

c S-D rats, gavage (Maltoni et al. 1985)

d B6C3F1 mice, gavage (NTP study 1984)

- Swiss mice, gavage (Maltoni et al. 1985)

f Wistar rats, gavage (Maltoni et al. 1985)

${ }^{8}$ Wistar rats, i.p. (Arfellini et al. 1985)

${ }^{b}$ SIV-50 rats, inhalation (Lutz and Schlatter 1977b). Exposure in a closed inhalation chamber: the amount of benzene administered was known

i BALB/c mice, i.p. (Arfellini et al. 1985)

Arrows indicate the rank positions of $\log _{10}$ OPI and of $\log _{10}$ CBI of benzene

Anil $=$ aniline. $\quad \mathrm{AAB}=4$-aminoazobenzene. $\mathrm{CCl}_{4}=$ carbon tetrachloride. $\mathrm{MMS}=$ methyl methane sulfonate. $\mathrm{CHCl}=$ chloroform. 2-NA $=2$-naphthylamine. NPY $=\mathrm{N}$-nitrosopyrrolidine. Eth $=$ ethionine. $\mathrm{EDB}=$ ethylene dibromide. $\mathrm{DAB}=\mathrm{N}, \mathrm{N}$-dimethyl-4-aminoazobenzene. $\mathrm{DMH}=1,2$-dimethylhydrazine. $\mathrm{NPI}=\mathrm{N}$-nitrosopiperidine. $\mathrm{NM}=\mathrm{N}$-nitrosomorpholine. AAT $=0$-aminoazotoluene. $\mathrm{MNNG}=\mathrm{N}$-methyl-N'nitro- $\mathrm{N}$-nitrosoguanidine. $\mathrm{MCA}=3$-methylcholanthrene. $\mathrm{AFB} 2=$ aflatoxin $\mathrm{B}_{2}$. EMS = ethyl methane sulfonate. $\mathrm{CP}=\mathrm{cyclophosphamide}$. $\mathrm{MDAB}=3^{\prime}$-methyl-4-dimethylaminoazobenzene. $\mathrm{ENU}=\mathrm{N}$-nitrosoethylurea. $\mathrm{BP}=$ benzo(a)pyrene. $\mathrm{DEN}=$ diethylnitrosamine. $\mathrm{AAF}=2-$ acetylaminofluorene. $\mathrm{HAAF}=\mathrm{N}$-hydroxy-2-acetylaminofluorene. $\mathrm{EC}=$ ethyl carbamate. Benzid = benzidine. $\mathrm{DMN}=$ dimethylnitrosamine. $\mathrm{MNU}=\mathrm{N}$-nitrosomethylurea. DES = diethylstilbestrol. NMust = nitrogen mustard. NHMI = nitrosohexamethyleneimine. MAMA = methylazoxymethanol acetate. $A F G 1=$ aflatoxin $G_{1}$. DMBA=7,12-dimethylbenz(a)anthracene. AFB1=aflatoxin $B_{1}$

creased 10 -fold from 10 to $100 \mathrm{ppm}$. In their work on micronuclei induction in polychromatic erythrocytes of CD-1 mice Hite et al. (1980) reported very large fluctuations in each time group after oral treatment, but the average trend was flattening of the response above $110 \mathrm{mg} / \mathrm{kg}$, corresponding to approximately 47 ppm according to EPA computations (Lee et al. 1983) (see also legend of Table 3 ).

Carcinogenic potency of mutagens in rodents seems to correlate semiquantitatively with adduct formation in liver DNA. In 1979 Lutz proposed an index of potency, the covalent binding index (CBI) for DNA adducts. In 1982, Parodi et al. discussed a procedure for the transformation of carcinogenicity data in terms of potency coefficient, OPI, which is, as a first approximation, the reciprocal of the $\mathrm{TD}_{50}$ index of Peto et al. (1984). From a database of carcinogenic potency (OPI) and liver DNA adducts in vivo (CBI) that we had published previously (Parodi et al. 1982) we were able to find a group of 36 chemicals for which both OPI and CBI data were available. These data, in ascending rank of potency are presented in Table 4. Potency data concerning benzene were inserted at the appropriate places, between the $1^{\text {st }}$ and $5^{\text {th }}$ position for OPI values and between the $3^{\text {rd }}$ and $9^{\text {th }}$ position for CBI values. For both OPI and CBI values benzene ranked amongst the weakest chemicals on the scales of potency. The data seem to suggest not only a qualita- 
tive correlation between carcinogenicity and adduct formation but also some degree of quantitative correlation.

\section{Kinetics and metabolism}

In humans, following benzene exposure at relatively low concentrations (amount of absorbed benzene $\sim 4-10 \mathrm{mg} / \mathrm{kg}$ ) (Teisinger et al. 1952; Nomiyama and Nomiyama $1974 \mathrm{a}, \mathrm{b}$ ), about $1 / 3$ is expired unchanged in the air and $2 / 3$ is excreted as metabolites in the urine within $24-48 \mathrm{~h}$. Approximately $87 \%$ is excreted as conjugates of phenol, $9 \%$ as conjugates of catechol, and $3 \%$ as conjugates of hydroquinone. In Swiss mice injected s.c. with 440 or $880 \mathrm{mg} / \mathrm{kg}$ benzene, approximately $2 / 3$ or $3 / 4$, respectively, is excreted unchanged in the air, and $1 / 3$ or $1 / 4$, respectively, is excreted as metabolites in the urine within $24 \mathrm{~h}$ (Andrews et al. 1977). Other studies on the urinary metabolites in mice (Longacre et al. 1981), have indicated that $81 \%$ is represented by phenol, $15 \%$ by catechol, and $4 \%$ by hydroquinone. Trace amounts of trans-trans muconic acid and of 1,2,4-trihydroxybenzene have also been

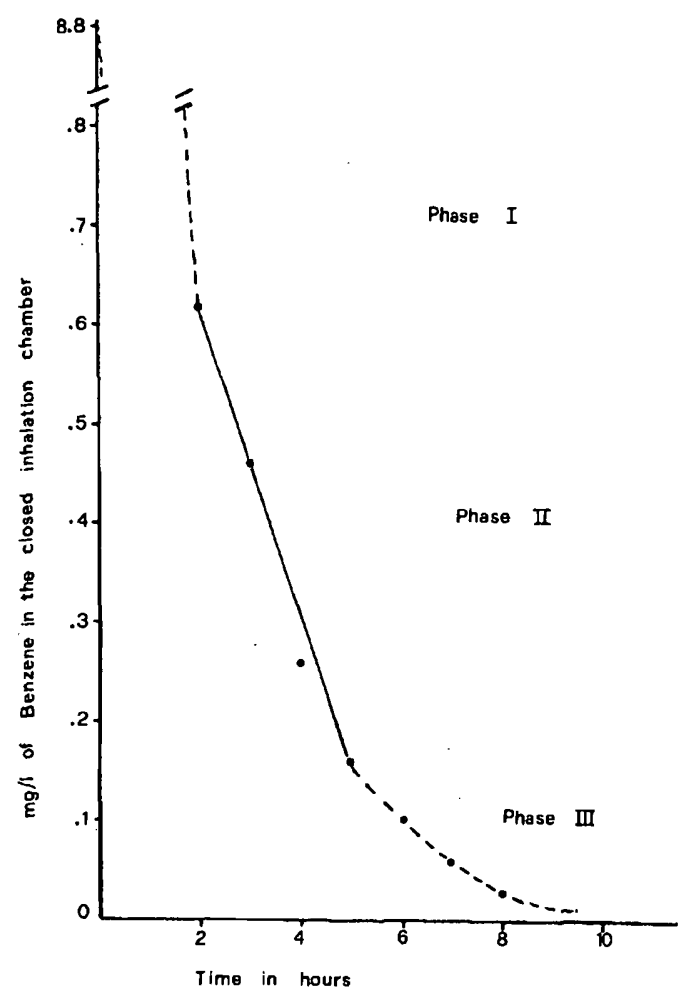

Fig. 3. Benzene concentration in the closed inhalation chamber as a function of time after injection of benzene into the chamber. In phase I, the major phenomenon is uptake and distribution of benzene in the rat. In phase II, benzene concentration decreases, essentially by zero order kinetics. In phase III, a shift to $1^{\text {st }}$ order kinetics occurs detected. Benzoquinones are, possibly, the electrophilic reacting intermediates; involvement of free radical mechanisms in phenol production has also been postulated (Johansson and Ingelman-Sundberg 1983). The same metabolites and similar ratios have been found in the urine of many other mammals (IARC $1982 \mathrm{a})$, which suggests that the major pathways of benzene metabolism are similar in all mammalian species tested so far.

In view of these considerations it seems acceptable to utilize the information obtained from experimental data (both short-term tests, metabolism, and pharmacokinetics) for an investigation of the relationship between dose and effects. In order to investigate the kinetics of uptake and metabolism of benzene by inhalation, adult male SIV-50 rats (270-340 g) were exposed to benzene evaporated in a closed inhalation system (a 21 desiccator) which has been described in detail elsewhere (Lutz and Schlatter 1977 a). In this system, expired carbon dioxide was adsorbed on soda lime and replaced by pure oxygen to keep the total pressure at a constant level. A typical time-course of benzene concentration in the desiccator is shown in Fig. 3: similar patterns were obtained for the experiments reported in Fig. 4. During the first $2 \mathrm{~h}$, the benzene concentration in the air rapidly decreased until an equilibrium was reached between absorption and exhalation. Within $2 \mathrm{~h}$, about $90 \%$ of the total amount of benzene had been taken up by the rat, about $10 \%$ was in the air. In a second phase, the level of benzene in the chamber decreased slowly, always in equilibrium with the internal level of benzene so that the rate of the metabolic turnover could be estimated from the decreased benzene concentration in the air.

Using different doses of benzene, the phase II data were analyzed for the period of time required to halve the benzene concentration determined at $2 \mathrm{~h}$. The results are shown in Fig. 4. In the range 200-1200 ppm (0.6-3.8 mg/l), the "halflife" of benzene was not a constant value but seemed to increase linearly with benzene concentration in the air. This suggests a zero order reaction, as if the overall metabolic system was saturated and working at a maximum constant speed. A regular feature of the experiments reported in Fig. 4 was the presence of a phase III, as reported in the example of Fig. 3: starting from about 50-30 ppm and below, the system was no longer saturated and first order decay of benzene levels was regularly observed.

Other findings seemed to confirm the observation that the rate of benzene metabolism is progressively saturated and flattened at concentrations above 30 ppm. The results of Andrews et al. (1977) seemed to indicate the same, when mice $(30 \mathrm{~g})$ were given ${ }^{3} \mathrm{H}$ benzene s.c., one group receiving $440 \mathrm{mg} / \mathrm{kg}$ and another group receiving $880 \mathrm{mg} / \mathrm{kg}$. The metabolites in 


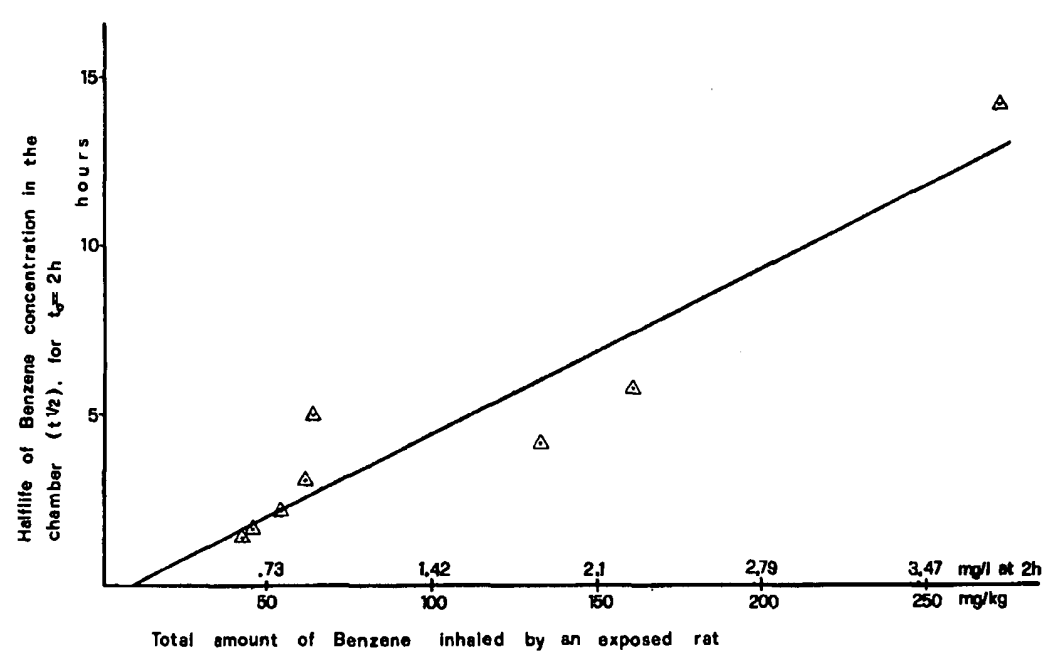

Fig.4. Reciprocal rate of benzene consumption in rats exposed to increasing concentrations of benzene (phase II of Fig. 3) in a closed inhalation chamber (Lutz and Schlatter 1977a). On the abscissa, the total amount of benzene applied to the chamber and expressed per kilogram body weight is given along with the corresponding concentration in the chamber after $2 \mathrm{~h}$. This second scale was obtained from a linear regression $(y=0.049+0.014 x, r=0.954$, $n=8$ ) between benzene concentration observed in single experiments and total amount of benzene applied urine were measured over a $24-\mathrm{h}$ period. The micromole equivalents of benzene found as metabolites in the urine were similar (60.1 and 72.6), irrespective of doubling the dose. Again, metabolic processes were saturated. Furthermore, rats inhaling benzene concentrations of $125,250,625$, or $1250 \mathrm{ppm}$ for $6 \mathrm{~h}$ excreted similar amounts of phenol in urine: hence benzene metabolism was already capacity-limited at 125 ppm (Gut and Frantik 1980).

Although no appropriate metabolism experiments are available in humans, the epidemiological data on the tumor incidence seem to suggest a flattening of the dose-response curve, for concentrations above $50 \mathrm{ppm}$ (Fig. 1).

\section{Conclusions}

The quantitative concordance between experimental data and epidemiological data seems to allow some degree of utilization of experimental results in human risk estimation. A few years ago, in response to the publication of the IARC report on benzene (IARC 1982 b) it was hotly debated (Sun 1982; Tomatis 1982) whether a linear extrapolation from 170 excess leukemia deaths (for a working lifetime exposure to $100 \mathrm{ppm}$ ) to 17 excess deaths ( 3 times background risk) for a $10 \mathrm{ppm}$ exposure could be defensible.

We have presented evidence that nonlinear doseresponse relationships suggested by the data on tumor induction in animals and man and on chromosomal damage in rodents might be explained by the metabolism of benzene which seems to become saturated in the dose range analyzed. A similar situation has been described previously for vinyl chloride where it was shown that metabolism (Gehring et al. 1978), macromolecular binding (Watanabe et al. 1978), and tumor induction (Maltoni and Lefemine 1975) all become saturated at inhalation exposure levels between 500 and $2500 \mathrm{ppm}$. The threshold with benzene appears to be at a lower concentration in the rat $(30-50 \mathrm{ppm})$ and it remains to be elucidated whether saturation of benzene metabolism in humans occurs in the same exposure range. Since this cannot be investigated in vivo, alternative methods might be required. One possibility would be the use of human tissue samples for the study of the maximum metabolic capacity in liver and bone marrow.

Because of the flattening of the curves at high exposure levels, probably due to saturation of the activation of benzene to reactive metabolites, the data obtained at the lowest exposure should be considered the most relevant as a basis for an extrapolation. Data obtained from dose levels above saturation will be of less value for defining the shape of the dose-response curves in the lower range. It is inevitable that a $10 \mathrm{ppm}$ exposure will result in a higher risk than if the high dose data are given the same weight, regardless of the model chosen. Our utilization of the available information tends to suggest that going from $100 \mathrm{ppm}$ to $10 \mathrm{ppm}$ for a 45 -year exposure the risk could be two to three times higher than that expected from a linear extrapolation. Usually benzene workers are exposed for an average of about 5-10 years and not for 45 years; therefore, we are dealing with a small increment of tumor incidence in comparison with the natural background of $1 / 4$ to $1 / 5$ cancer-related deaths. It is interesting to note that the European Economic Community (COM(85)669 def., Bruxelles, December 3, 1985 ) is considering the possibility of putting the limit of occupational exposure at $5 \mathrm{ppm}$ instead of $10 \mathrm{ppm}$, as generally accepted by different countries.

Acknowledgements. This work was supported by grants from Progetto Finalizzato "Oncologia" C.N.R. (contract nos. 86.00444.44 and 86.00697.44), Progetto Finalizzato "Medicina Preventiva e Ria- 
bilitativa" C.N.R. (contract no. 86.02062.56), Ministero della Pubblica Istruzione, Rome and Associazione Italiana per la Ricerca sul Cancro, Milan, Italy.

\section{References}

Andrews LS, Lee EW, Witmer CM, Kocsis JJ, Snyder R (1977) Effects of toluene on the metabolism, disposition and hematopoietic toxicity of ${ }^{3} \mathrm{H}$-benzene. Biochem Pharmacol 26:293-300

Arfellini G, Grilli S, Colacci A, Mazzullo M, Prodi G (1985) In vivo and in vitro binding of benzene to nucleic acids and proteins of various rat and mouse organs. Cancer Lett 28:159-168

Ashby J, de Sertes FJ, Draper M, Ishidate M, Jr, Margolin BM, Matter B, Shelby MD (1985) Overview and conclusions of the IPCS collaborative study on in vitro assay systems. In: Ashby FJ, de Serres FJ et al. (eds) Progress in mutation research 5:117-174. Elsevier Science Publishers, Amsterdam (WHO Geneve)

Choy WN, MacGregor JT, Shelby MD, Marnopot RR (1985) Induction of micronuclei by benzene in $\mathrm{B} 6 \mathrm{C} 3 \mathrm{~F} 1$ mice: retrospective analysis of peripheral blood smears from the NTP carcinogenesis bioassay. Mutat Res 143:55-59

Cronkite EP, Drew RT, Inone T, Bullis JE (1985) Benzene hematotoxicity and leukemogenesis. Am J Ind Med 7:447-456

Dean BJ (1985) Recent findings on the genetic toxicology of benzene, toluene, xylenes and phenols. Mutat Res 154:153-181

ECETOC Technical Report No. 16 (1984) A review of recent literature on the toxicology of benzene. European Chemical Industry Ecology and Toxicology Center, Brussels

Erexson JL, Wilmer JL, Auman CD, Kligerman AD (1984) Induction of sister chromatid exchanges and micronuclei in male DBA/ 2 mice after inhalation of benzene. Environ Mutagen $6: 408$

Gad-el-Karim MM, Harper BL, Legator MS (1984) Modifications in the myeloclastogenic effect of benzene in mice with toluene, phenobarbital, 3-methylcholanthrene, Aroclor 12.54 and SKF 525-A. Mutat Res 135:225-243

Gehring PJ, Watanabe PG, Park CN (1978) Resolution of dose-response toxicity data for chemicals requiring metabolic activation: example - vinyl chloride. Toxicol Appl Pharmacol 44:581591

Gold LS, Sawyer CB, Magaw R, Backman GM, de Veciana M, Levinson R, Hooper NK, Havender WR, Bernstein L, Peto R, Pike MC, Ames BN (1984) A carcinogenic potency database of the standardized results of animal bioassays. Environ Health Perspect 58:9-319

Goldstein BD (1985) Risk assessment and risk management of benzene by the Environmental Protection Agency. In: Hoel DG, Merril RA, Perera FP (eds) Risk quantitation and regulatory policy. Cold Spring Harbor Laboratory, Banbury Rep 19:293304

Gut I, Frantik E (1980) Kinetics of benzene metabolism in rats in inhalation exposure. Arch Toxicol (Suppl) 4:315-317

Hite M, Pecharo M, Smith I, Thornton S (1980) The effect of benzene in the micronucleus test. Mutat Res 77:149-155

IARC Monographs on the Evaluation of Carcinogenic Risk of Chemicals to Humans (1982a) "Benzene". International Agency for Research on Cancer, Lyon 29:93-148

IARC Monographs on the Evalutation of Carcinogenic Risk of Chemicals to Humans (1982 b) "Annex". International Agency for Research on Cancer, Lyon 29:391-398

IARC Monographs on the Evaluation of Carcinogenic Risk of Chemicals to Humans (1982c). International Agency for Research on Cancer, Lyon (Suppl) 4:56-57

Johansson I, Ingelman-Sundberg M (1983) Hydroxyl radical mediated, cytochrome P-450-dependent metabolic activation of benzene in microsomes and reconstituted enzyme systems from rabbit liver. J Biol Chem 258:7311-7316
Kalf GF, Snyder R, Rushmore TH (1985) Inhibition of RNA synthesis by benzene metabolites and their covalent binding to DNA in rabbit bone marrow mitochondria in vitro. Am J Ind Med 7:485-492

Lee SD, Dourson M, Mukerjee D, Stara JF, Kawecki J (1983) Assessment of benzene health effects in ambient water. In: Mehlman MA (ed) Advances in modern environmental toxicology. Princeton Scientific Publishers, Princeton 4:91-125

Longacre SL, Kocsis JJ, Snyder R (1981) Influence of strain differences in mice on the metabolism and toxicity of benzene. Toxicol Appl Pharmacol 60:398-409

Lutz WK (1979) In vivo covalent binding of organic chemicals to DNA as a quantitative indicator in the process of chemical carcinogenesis. Mutat Res 65:289-356

Lutz WK, Schlatter C (1977a) A closed inhalation chamber for quantitative metabolism studies of volatile compounds with small laboratory animals. Toxicol Lett 1:83-87

Lutz WK, Schlatter C (1977b) Mechanism of the carcinogenic action of benzene: irreversible binding to rat liver DNA. Chem Biol Interact 9:253-257

Maltoni C (1975) The value of predictive experimental bioassays in occupational and environmental carcinogenesis. Ambio 4:10

Maltoni C, Lefemine G (1975) Carcinogenicity assays of vinyl chloride: current results. Ann NY Acad Sci 246:195-224

Maltoni C, Scarnato C (1979) First experimental demonstration of the carcinogenic effects of benzene. Long-term bioassay on Sprague-Dawley rats by oral administration. Med Lav 70:352357

Maltoni C, Conti B, Cotti G, Belpoggi F (1985) Experimental studies on benzene carcinogenicity at the Bologna institute of oncology: current results and ongoing research. Am J Ind Med 7:415-446

Nomiyama K, Nomiyama H (1974a) Respiratory retention, uptake and excretion of organic solvents in man. Benzene, toluene, $\boldsymbol{n}$ hexane, trichloroethylene, acetone, ethylacetate and ethyl alcohol. Int Arch Arbeitsmed 32:75-83

Nomiyama K, Nomiyama H (1974b) Respiratory elimination of organic solvents in man. Benzene, toluene, $n$-hexane, trichloroethylene, acetone, ethylacetate and ethyl alcohol. Int Arch Arbeitsmed 32:85-91

NTP (National Toxicology Programme) (1984) NTP Technical Report: Toxicology and carcinogenesis studies of benzene in F344/ $\mathrm{N}$ rats and B6C3F1 mice (gavage studies). NTP-83-072, NIH publication 84-2545. US Dept of H.H.S.

Ott MG, Townsend JC, Fishbeck WA, Langner RA (1978) Mortality among individuals occupationally exposed to benzene. Arch Environ Health 33:3-9

Parodi S, Taningher M, Santi L (1982) Alkaline elution in vivo: fluorimetric analysis in rats. Quantitative predictivity of carcinogenicity, as compared with other short-term tests. In: Bridges BA, Butterworth BE, Weinstein IB (eds) Indicators of genotoxic exposure. Cold Spring Harbor Laboratory, Banbury Rep 13:137-155

Parodi S, Balbi C, Abelmoschi ML, Pala M, Russo P, Santi L (1983) Studies on DNA damage: discordant responses of rate of DNA disentanglement (viscosimetrically evaluated) and alkaline elution rate, obtained for several compounds. Cell Biophys 5:285300

Peto R, Pike MC, Bernstein L, Gold LS, Ames BN (1984) The TD 50 : a proposed general convention for the numerical description of the carcinogenic potency of chemicals in chronic-exposure ani$\mathrm{mal}$ experiments. Environ Health Perspect 58:1-8

Rall DP (1977) Species differences in carcinogenic testing. In: Wiatt HH, Watson JD, Winsten JA (eds) Origins of human cancer. Cold Spring Harbor Laboratory, Book C, pp 1383-1390

Rinsky RA, Young RJ, Smith AB (1981) Leukemia in benzene workers. Am J Ind Med 2:217-245 (this study completes the fol- 
low-up by Infante PF, Rinsky RA, Wagoner JK, Young RJ (1977) Lancet II:76-78)

Snyder CA, Goldstein BD, Sellakumar A, Bromberg I, Laskin S, Albert RE (1980) The inhalation toxicology of benzene: incidence of hematopoietic neoplasms and hematotoxicity in AKR/J and C57BL/6J mice. Toxicol Appl Pharmacol 54:323-331

Styles JA, Richardson CR (1984) Cytogenetic effect of benzene: dosimetric studies on rats exposed to benzene vapour. Mutat Res 135:203-209

Sun M (1982) Risk estimate vanishes from benzene report. Science 217:914-915
Teisinger J, Bergerova-Fiserova V, Kudrne J (1952) The metabolism of benzene in man. Pracov Lek (Poi) 4:175-188

Tomatis L (1982) IARC benzene report. Science 218:214

Vigliani EC (1976) Leukemia associated with benzene exposure. Ann NY Acad Sci 271:143-151

Watanabe PG, Zempel JA, Pegg DG, Gehring PJ (1978) Hepatic macromolecular binding following exposure to vinyl chloride. Toxicol Appl Pharmacol 44:571-579

Received January 23, 1987/Accepted February 25, 1987 